\title{
Implementasi Kurikulum 2013 Pada Mata Pelajaran IPS Di SMP Negeri 8 Singaraja
}

\author{
Luh Putu Yuni Widiantari*1, M. Rudi Irwansyah² \\ 1,2Program Studi Pendidikan Ekonomi \\ Universitas Pendidikan Ganesha \\ Singaraja, Indonesia
}

\section{e-mail: yuniwidian30@gmail.com*1, rudi.irwansyah@undiksha.ac.id}

\begin{abstract}
Abstrak
Riwayat Artikel Tanggal diajukan:

4 Januari 2021

Tanggal diterima : 14 April 2021

Tanggal dipublikasikan: 25 Juni 2021

Kurikulum 2013 dikembangan dengan tujuan untuk dapat dijadikan acuan dalam proses peningkatan kualitas pembelajaran di sekolah yang melibatkan guru dan siswa. Penelitian ini adalah penelitian deskriptif yang bertujuan untuk menganalisa dan mendeskripsikan implementasi kurikulum 2013 pada mata pelajaran IPS di SMP Negeri 8 Singaraja. Sejalan dengan metode pembelajaran daring dalam situasi pandemi COVID-19, penelitian ini mengamati proses pembelajaran yang diselenggarakan secara daring tersebut dengan memperhatikan aspekaspek penting yang terlibat dalam proses tersebut. Metode yang digunakan dalam pengumpulan data yaitu wawancara, observasi dan dokumentasi. Sedangkan teknik analisis data yang digunakan yaitu Data Reduction (Reduksi Data), Data Display (Penyajian Data), dan Conclution Drawing/Verification (Penarikan Kesimpulan). Penelitian ini menunjukkan hasil bahwa Implementasi kurikulum 2013 di masa pandemi COVID-19 ini terkait dengan standar kompetensi lulusan telah dinilai dari secara tidak langsung melalui mekanisme pembelajaran online. Standar isi dilaksanaan pembelajaran saintifik melalui platform media sosial dengan memberikan materi pelajaran untuk membuat siswa aktif dan mampu berpikir ilmiah. Standar proses dilihat dari keaktifan dan kemampuan peserta didik memahami materi yang telah diajarkan. Dan standar penilaian dilihat dari parstisipasi aktif selama berlangsunya pembelajaran daring.
\end{abstract}

Pengutipan:

Widiantari, L. P. Y., Irwansyah M. R. (2021).

Implementasi Kurikulum 2013

Pada Mata

Pelajaran IPS Di

SMP Negeri 8

Singaraja. Jurnal Pendidikan

Ekonomi Undiksha

13(1), 60-71

http://dx.doi.org/10.

23887/jjpe.v13i1.30 $\underline{918}$
Kata kunci: kurikulum 2013; standar kompetensi lulusan; standar proses; standar isi; standar penilaian.

\begin{abstract}
The 2013 curriculum was developed with the aim of being able to be used as a reference in the process of improving the quality of learning in schools involving teachers and students. This research is a descriptive study that aims to analyze and describe the implementation of the 2013 curriculum in social studies subjects at SMP Negeri 8 Singaraja. In line with the online learning method in the Covid-19 pandemic situation, this study observes the learning process that is organized online by paying attention to the important aspects involved in the process. The methods used in data collection are interviews, observation and documentation. While the data analysis techniques used are Data Reduction, Data Display, and Conclusion Drawing / Verification. This research shows the results that the implementation of the 2013 curriculum during the COVID19 pandemic is related to the competency standards of graduates that have been assessed indirectly through an online learning mechanism. Content standards are carried out in scientific learning through social media platforms by providing subject matter to make students active and able to think scientifically. Process standards are seen from the activeness and ability of students to understand the material that has
\end{abstract}


been taught. And the standard of assessment is seen from active participation during online learning.

Keywords : curricullum 2013; graduate competence standar; process standard; content; evaluation standard.

\section{PENDAHULUAN}

Kurikulum 2013 adalah kurikulum yang berlaku dalam Sistem Pendidikan Indonesia saat ini. Kurikulum 2013 diharapkan mampu membawa perubahan pada sistem pendidikan di Indonesia.

Kondisi empiris lain berhubungan dengan hasil riset PISA (Program for International Student Assessment), studi yang memfokuskan pada literasi bacaan, matematika, dan IPA menunjukkan peringkat Indonesia baru bisa menduduki 10 besar terbawah dari 65 negara. Hasil Riset TIMSS (Trends in International Mathe matics and Science Study) menunjukkan siswa Indonesia berada pada ranking amat rendah dalam kemampuan, (1) memahami informasi yang komplek, (2) teori, analisis dan pemecahan masalah, (3) pemakaian alat, prosedur dan pemecahan masalah dan (4) melakukan investigasi. Hasil-hasil ini menunjukkan perlu ada perubahan orientasi kurikulum, dengan tidak membebani peserta didik dengan konten namun pada aspek kemampuan esensial yang diperlukan semua warga negara untuk berperan serta dalam membangun negaranya pada abad 21 (Setiana, 2014).

Kurikulum 2013 memiliki sejumlah keunggulan dibandingkan kurikulum sebelumnya (Prastowo, 2015). Mulyasa (2018) mengemukakan pengertian Kurikulum 2013 sebagai perubahan kurikulum yang disesuaikan dengan penataan Standar Nasional Pendidikan (SNP), terutama Standar Kompetensi Lulusan (SKL), Standar Isi (SI), Standar Proses (SP), dan Standar Penilaian Pendidikan (SPP). Kesemua elemen tersebut berkaitan satu dengan yang lainnya dan dituangkan dalam standar proses (Priyatni, 2017).

Namun pada kenyataannya, implementasi kurikulum 2013 masih mendapatkan banyak hambatan seperti yang dialami para guru disekolah terutama di SMP Negeri 8 Singaraja, hal ini didasari pada hasil observasi dan tanya jawab peneliti terhadap guru dalam mata pelajaran IPS di SMP Negeri 8 Singaraja. Hasil pertemuan tersebut menyebutkan bahwa, pelaksanaan kurikulum 2013 masih menemui kendala atau kekurangan diantaranya kesulitan para guru mengenai pemahaman tentang kompetensi Inti (KI) dan Kompetensi Dasar (KD), proses pembelajaran yang masih berpusat pada guru, serta kesulitaan guru terhadap sistem penilaian dalam kurikulum 2013 karena para guru merasa kurang dilatih untuk melaksanakan Kurikulum 2013 dalam kegiatan pembelajaran khususnya pembelajaran IPS. Mengenai tujuan ilmu pengetahuan sosial (pendidikan IPS) yaitu untuk mendidik dan memberi bekal kemampuan dasar kepada siswa untuk mengembangkan diri sesuai dengan bakat, minat, kemampuan dan lingkungannya, serta berbagai bekal bagi siswa untuk melanjutkan pendidikan ke jenjang yang lebih tinggi (Solihatin, 2011).

Adapun beberapa penelitian yang berkaitan dengan analisa kurikulum 2013 sudah pernah dilakukan. Penelitian (Afifah, 2017) ini menunjukkan bahwa Implementasi kurikulum 2013 di MTsN Malang 1 menggunakan pendekatan implementasi kuikulum Mutual Adaption, guru IPS masih mengalami beberapa kendala dan menyesuaikan dengan kondisi riil di lapangan (Jannah, 2013) menunjukkan bahwa Implementasi kurikulum 2013 pada pembelajaran IPS di SMP Negeri 1 Muntilan mencakup tiga proses yaitu perencanaan, pelaksanaan dan penilaian pembelajaran.

Penelitian (Fussalam \& Elmiati, 2018) ini menunjukkan bahwa implementasi kurikulum 2013 disambut positif oleh SMP Negeri 2 Sarolangun. Dikarenakan metode pembelajaran pada $\mathrm{K} 13$ sesuai dengan proses pembelajaran di era globalisasi, yaitu proses pembelajaran menggunakan metode Scientific Approach. 
Penelitian (Mastur, 2017) ini menunjukkan bahwa pelaksanaan pembelajaran menggunakan pendekatan ilmiah (saintific), penilaian hasil belajar dilakukan dengan menggunakan teknik tes, tertulis maupun lisan, juga teknik non tes, pengamatan kinerja dan sikap.

Penelitian yang dilakukan oleh penulis dalam artikel ini dilakukan di SMP Negeri 8 Singaraja yang merupakan sekolah baru yang ada di Singaraja dimana sekolah ini dibangun karena diberlakukannya kebijakan zonasi PPDB SMPN Tahun ajaran 2017/208. Di daerah zonasi tersebut terdapat banyak siswa tamatan SD dari empat desa bertetangga di wilayah Kecamatan Buleleng yaitu Desa Pemaron, Desa Anturan, Desa Tukadmungga, dan Desa Kalibukbuk yang terancam drop out (DO). Maka diambil keputusan untuk membangun Sekolah baru yaitu SMP Negeri 8 Singaraja yang disepakati dalam rapat dengan Komisi IV DPRD Buleleng dan Disdikpora Buleleng dengan kepala desa (Perbekel) dari empat desa bertetangga.

Penulis melakukan penelitian di SMP Negeri 8 Singaraja karena Sekolah ini merupakan sekolah baru yang beroperasi kurang lebih 3 tahun sehingga dalam penerapan kurikulum 2013 khususnya pada mata pelajaran IPS perlu adanya kesiapan lebih dari pihak sekolah untuk dapat menunjang segala aktivitas yang berkaitan dengan penerapan kurikulum 2013.

Berdasarkan uraian tersebut, ada 4 rumusan masalah yang akan dijabarkan dalam penelitian ini yaitu: bagaimana implementasi kurikulum 2013 dilihat dari standar kompetensi lulusan, standar isi, standar proses dan standar penilaian pada mata pelajaran IPS di SMP Negeri 8 Singaraja. Namun di era pandemic Covid19 ini, peneliti tetap melakukan pengamatan proses pembelajaran meskipun dilakukan secara daring. Di SMP Negeri 8 Singaraja kelas VII dan VIII sudah menggunakan Kurikulum 2013. Dalam keempat standar tersebut adapun aspekaspek pendukung yang menjadi referensi penelitian adalah perangkat pembelajaran. Emusti \& Karel (2019) menyebutkan Penyusunan perangkat mata pelajaran ini disesuaikan dengan keadaan dan kemampuan setiap jenjang pendidikan dalam penyelenggaraan pendidikan tersebut serta kebutuhan lapangan kerja.

Dalam penelitian ini penulis melibatkan Kepala sekolah, Waka Kurikulum, Guru, dan siswa untuk dapat memperoleh informasi yang diperlukan dalam penyusunan skripsi, kemudian hambatan dalam menerapkan kurikulum 2013 serta solusi yang dilakukan untuk mengatasi hambatan tersebut.

\section{Rumusan Masalah}

Berdasarkan latar belakang dan pembahasan masalah di atas, maka permasalahan penelitian dapat dirumuskan sebagai berikut.

1. Bagaimanakah implementasi Kurikulum 2013 mata pelajaran IPS dilihat dari standar kompetensi lulusan di SMP Negeri 8 Singaraja?

2. Bagaimanakah implementasi Kurikulum 2013 mata pelajaran IPS dilihat dari Standar isi di SMP Negeri 8 Singaraja?

3. Bagaimanakah implementasi Kurikulum 2013 mata pelajara IPS dilihat dari standar nasional pendidikan yaitu standar proses di SMP Negeri 8 Singaraja?

4. Bagaimanakah implementasi Kurikulum 2013 mata pelajaran IPS dilihat dari standar penilaian pendidikan di SMP Negeri 8 Singaraja?

\section{Tujuan Penelitian}

Berdasarkan latar belakang dan pembahasan masalah di atas, maka yang menjadi tujuan penelitian dapat dirumuskan sebagai berikut.

1. Menganalisa dan mendeskripsikan implementasi Kurikulum 2013 mata pelajaran IPS dilihat dari standar kompetensi lulusan di SMP Negeri 8 Singaraja.

2. Menganlisa dan mendeskripsikan implementasi Kurikulum 2013 mata pelajaran IPS dilihat dari Standar isi di SMP Negeri 8 Singaraja.

3. Menganalisa dan mendeskripsikan implementasi Kurikulum 2013 mata pelajara IPS dilihat dari standar 
nasional pendidikan yaitu standar proses di SMP Negeri 8 Singaraja.

4. Menganalisa dan mendeskripsikan implementasi Kurikulum 2013 mata pelajaran IPS dilihat dari standar penilaian pendidikan di SMP Negeri 8 Singaraja.

\section{METODE}

Penelitian ini menggunakan metode penelitian deskriptif. Pada umumnya penelitian deskriptif bertujuan untuk mendeskripsikan atau menjelaskan suatu keadaan, peristiwa, atau sesuatu yang terkait dengan variabel-variabel yang dijelaskan baik dengan angka-angka maupun kata-kata (Setyosari, 2012). Dalam penelitian ini yaitu untuk mengetahui Bagaimana Implementasi kurikulum 2013 Mata Pelajaran IPS di SMP Negeri 8 Singaraja.

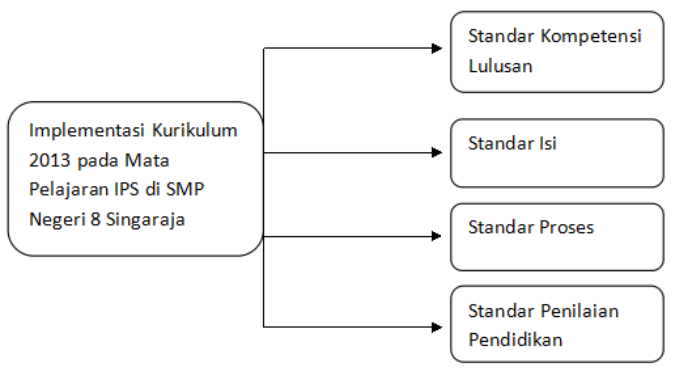

Gambar 3.1

Rancangan Penelitian

Tempat dilaksanakannya penelitian ini di SMP Negeri 8 Singaraja. Alasan peneliti memilih sekolah ini karena SMP Negeri 8 Singaraja merupakan sekolah baru yang sudah menerapkan kurikulum 2013. Namun untuk kelas IX masih menggunakan KTSP sedangkan kelas VII dan VIII sudah menggunakan kurikulum 2013.

Dalam menerapkan kurikulum 2013 perlu adanya kesiapan yang lebih dari pihak sekolah dalam menunjang kegiatan pembelajaran kurikulum 2013 baik dari segi sarana prasarana maupun yang lainnya. Waktu yang digunakan peneliti untuk melaksanakan penelitian ini sejak tanggal dikeluarkannya ijin penelitian dalam kurun waktu kurang lebih 2 (dua) bulan, yaitu 1 bulan pengumpulan data dan 1 bulan pengolahan data yang meliputi penyajian dalam bentuk skripsi dan proses bimbingan berlangsung. Dalam penelitian ini metode pengumpulan data yang digunakan sebagai berikut.

\section{Metode Wawancara}

Wawancara merupakan pembicaraan yang mempunyai tujuan dan didahului beberapa pertanyaan informal. Peneliti datang berhadapan muka secara langsung dengan responden atau subjek yang diteliti (Sukardi, 2012). Wawancara ini dilakukan dengan Kepala Sekolah, Wakil Kepala Sekolah Bidang Kurikulum, Guru mata pelajaran IPS kelas VII dan VIII serta beberapa siswa SMP Negeri 8 Singaraja, yang dilakukan pada saat observasi dan pengambilan data ini untuk menggali informasi terkait dengan standar kompetensi lulusan, standar isi, standar proses, dan standar penilaian.

\section{Metode Observasi (Pengamatan)}

Siregar (2013), menjelaskan bahwa observasi atau pengamatan langsung adalah kegiatan pengumpulan data dengan melakukan penelitian langsung terhadap kondisi lingkungan objek penelitian yang mendukung kegiatan penelitian, sehingga didapat gambaran secara jelas tentang kondisi objek penelitian tersebut. Dalam penelitian ini, penulis melakukan wawancara terhadap kepala sekolah terkait implementasi kurikulum 2013 mata pelajaran IPS di SMP Negeri 8 Singaraja. Peneliti melakukan pengamatan terhadap tindakan yang dilakukan guru, penguasaan materi, dan metode yang digunakan.

\section{Metode Dokumentasi}

Teknik penumpulan data yang dilakukan untuk mengumpulkan dan memperoleh informasi dari bermacammacam sumber tertulis atau dokumen yang ada pada responden serta melakukan pencatatan terhadap sumber-sumber informasi khusus seperti karangan, buku, undang-undang dan hal lain yang akan menjadi objek penelitian. "Hasil penelitian dari obeservasi atau wawancara akan lebih kredibel/ dapat dipercaya kalau didukung oleh sejarah pribadi, kehidupan di masa kecil, di sekolah, di tempat kerja, di masyarakat, dan autobiografi" (Sugiyono, 
2015). Pada penelitian ini, dokumentasi yang diperoleh yaitu data yang masih berhubungan dengan implementasi Kurikulum 2013 pada mata pelajaran IPS di SMP Negeri 8 Singaraja.

\section{Instrumen Penelitian}

Afrizal (2016) menyatakan bahwa instrumen penelitian adalah alat-alat yang diperlukan atau yang dipergunakan untuk mengumpulkan data. Ini berarti, dengan menggunakan alat-alat tersebut data dikumpulkan. Instrumen dalam penelitian yaitu berupa pedoman wawancara. Jadi pedoman wawancara digunakan untuk mewawancarai Kepala Sekolah, Wakil Kepala Sekolah Bidang Kurikulum, Guru IPS dan siswa SMP Negeri 8 Singaraja.

\section{Metode dan Teknik Analisis Data}

Afrizal (2016) menyatakan bahwa analisis data didefinisikan sebagai suatu proses yang sistematis untuk menentukan bagian-bagian dan saling keterkaitan antara bagian-bagian dan keseluruhan dari data yang telah dukumpulkan untuk menghasilkan klasifikasi atau tipologi. Dalam penelitian ini, data-data diperoleh dari hasil observasi, wawancara, dan dokumentasi kemudian dianalisis menggunakan teknik deskriptif-kualitatif, yakni mendeskripsikan lewat uraian dan penjelasan. Teknik analisis data dalam penelitian ini menggunakan model Miles and Huberman dalam (Sugiyono, 2014). Adapun langkah-lamgkah dalam analisi data sebagai berikut:

\section{Data Reduction (Reduksi Data)}

Reduksi data berarti merangkum, memilih dan memilih hal-hal yang pokok, memfokuskan pada hal-hal yang penting, dicari tema dan polanya. Dalam penelitian ini maka dilakukan dengan penyederhanaan data yang diperoleh dari hasil observasi, wawancara, dan dokumentasi terhadap guru mata pelajaran IPS di SMP Negeri 8 Singarja.

\section{Data Display (Penyajian Data) \\ Dalam penelitian kualitatif, penyajian} data bisa dilakukan dalam bentuk uraian singkat, bagan, hubungan antar kategori, flowchart dan sejenisnya. Dengan mendisplaykan data, maka memudahkan untuk memahami apa yang terjadi, merencanakan kerja selanjutnya berdasarkan apa yang telah dipahami.

\section{Conclusion Drawing/Verification}

Langkah terakhir dalam analisis data kualitatif adalah penarikan kesimpulan dan verifikasi. Kesimpulan awal yang dikemukakan masih bersifat sementara dan akan berubah bila idak ditemukan bukti-bukti yang kuat yang mendukung pada tahap pengumpulan data berikutnya. Tetapi apabila kesimpulan yang dikemukakan pada tahap awal didukung oleh bukti-bukti yang valid dan konsisten saat peneliti kembali ke lapangan mengumpulkan data, maka kesimpulan yang dikemukakan merupakan kesimpulan yang kredibel.

\section{HASIL DAN PEMBAHASAN}

Di tahun 2020, proses pembelajaran di semua aspek pendidikan formal dan non formal menjadi tahun yang berat. Hingga saat ini Indonesia masih dilanda pandemic Covid-19. COVID-19 merupakan penyakit menular yang disebabkan oleh sindrom pernapasan akut coronavirus 2 (serever acute resipiratory syndrome coronavirus2 atau SARSCoV -2). Virus ini merupakan bagian dari Coronavirus yang dapat menyerang hewan. Ketika menyerang manusia, Coronavirus biasanya menyebabkan penyakit infeksi saluran pernapasan, seperti flu, MERS (Middle East Respiratory Syndrome), dan SARS (Serever Acute Resipiratory Syndrome). Covid-19 sendiri merupakan coronavirus jenis baru yang ditemukan di Wuhan, Hubei, China pada tahun 2019 (Adib Rifqi Setiawan \& Surotul IImiyah, 2020). Hal ini tentu saja berdampak ada berhentinya proses interaksi yang melibatkan banyak orang, salah satunya kegiatan belajar di sekolah. Segala daya dan upaya sudah dilakukan pemerintah guna memperkecil kasus penularan Covid-19. Tak terpungkiri salah satu nya adalah kebijakan belajar online, atau dalam jaringan (daring) untuk seluruh siswa/i hingga mahasiswa/i karena adanya pembatasan sosial.

Menteri Pendidikan dan Kebudayaan Republik Indonesia mengeluarkan Surat 
Edaran Nomor 4 Tahun 2020 Tentang Pelaksanaan Kebijakan Pendidikan Dalam Masa Darurat Penyebaran Coronavirus Disease (Covid-19) poin ke 2 yaitu proses belajar dari rumah dilaksanakan dengan ketentuan sebagai berikut.

1. Belajar dari rumah melalui pembelajaran daring/jarak jauh dilaksanakan untuk memberikan pengalaman belajar yang bermakna bagi siswa, tanpa terbebani tuntutan menuntaskan seluruh capaian kurikulum untuk kenaikan kelas maupun kelulusan.

2. Belajar dari rumah dapat difokuskan pada pendidikan kecakapan hidup antara lain mengenai pandemic Covid19. Aktivitas dan tugas pembeljaran belajar dari rumah dapat bervariasi antarsiswa, sesuai minat dan kondisi masing-masng, termasuk mempertimbangkan kesenjangan akses/fasilitas belajar dirumah.

3. Bukti atau produk aktivitas belajar dari rumah diberi umpan balik yang bersifat kualitatif dan berguna dari guru, tanpa diharuskan memberi skor/nilai kuantitatif.

4. Pemaduan penggunaan sumber belajar tradisional (offline) dan online adalah suatu keputusan demokratis untuk menjembatani derasnya arus penyebaan sumber belajar elektronik (e-learning) dan kesulitan melepaskan diri dari pemanfaatan sumber-sumber belajar yang digunakan dalam ruang kelas.

Artinya, e-learning bagaimanapun canggihnya teknologi yang digunakan belum mampu menggantikan pelaksanaan pembelajaran tatap muka karena metode interaksi tatap muka konvensional masih jauh lebih efektif dibandingkan pembelajaran online atau e-learning.

Namun dari kebijakan yang dikeluarkan tentunya tidak dapat memastikan semuanya akan berjalan sebagaimana mestinya disemua kalangan, khusus nya sekolah didesa-desa yang kekurangan fasilitas berupa teknologi terpadu guna menunjang proses pembelajaran belajar online. Kurangnya biaya dan fasilitas yang memadai antara guru dengan siswa/i nya membuat proses pembelajaran online tidaklah seefektif yang diharapkan.

Dalam mewujudkan tujuan pendidikan nasional diperlukan kualifikasi kemampuan lulusan yang dituangkan dalam Standar Kompetensi Lulusan (SKL) SMP/MTs/SMPLB/Paket B pada Permendikbud Nomor 20 Tahun 2016. SKL yang harus dicapai dari suatu pendidikan pada jenjang pendidikan dasar yaitu.

Berdasarkan hasil wawancara dengan guru IPS kelas VIII terkait dengan penerapan kurikulum 2013 jika dilihat dari standar kompetensi lulusan.

Penerapan kurikulum 2013 terkait standar kompetensi lulusan di SMP Negeri 8 Singaraja pada situasi pandemic COVID19 ini untuk dimensi sikap telah dinilai dari perilaku secara tidak langsung saat pembelajaran online. Pembelajaran di SMP N 8 Singaraja sudah menggunakan sistem daring. adapun aplikasi yang dipakai oleh beberapa guru yaitu metode diskusi dengan menggunakan WA group, metode ceramah dengan menggunakan video aplikasi zoom, metode resitasi dengan siswa diberikan materi kemudian disuruh untuk membuat resume, metode problem based learning dengan cara siswa diberikan sebuah kasus untuk kemudian dipecahkan masalahnya bersama teman kelompoknya ataupun juga bisa di pecahkan secara individu, metode discovery learning dengan cara siswa mengembangkan dirinya menjadi lebih aktif dan mandiri dalam mencari jawabannya, metode debat dengan menggunakan group chat dari murid sekelas dengan di pimpin guru, dan masih banyak lainnya.

Akan tetapi dari sekaian banyak aplikasi daring tersebut untuk mata pelajaran IPS hanya menggunakan aplikasi group WA (whats app). Dikarenakan penggunaannya yang mudah dan praktis jika diterapkan untuk pembelajaran daring pada mata pelajaran IPS. Penilaian dimensi sikap dinilai dari keaktifan peserta didik dalam merespon komunikasi guru dalam memberikan tugas di aplikasi group WA tersebut. Penilaian terhadap dimensi pengetahuan dilakukan dengan memberikan pertanyaan ataupun tugastugas kepada peserta didik. Ketepatan batas waktu pengumpulan dari jawaban 
tersebut, serta kreativitas peserta didik dalam mengerjakan tugas merupakan aspek dalam penilaian dimensi pengetahuan sekaligus dimensi keterampilan masing-masing peserta didik.

Implementasi Kurikulum 2013 mata pelajaran IPS dilihat dari Standar Isi di SMP Negeri 8 Singaraja.

Pelaksanaan Kurikulum 2013 dalam mata pelajaran IPS, materi yang dikembangkan harus mengacu pada pencapaian $\mathrm{KI} 1$ dan $\mathrm{KI} 2$. Misal: pembelajaran tentang tema "Penduduk dan Pemanfaatan Potensi Sumber Daya Alam" dalam KD 3 dan KD 4 harus mendukung pencapaian KD 2 (sikap peduli) dan KD 1 (sikap menghargai keberadaan potensi sumber daya).

Muatan pembelajaran IPS di SMP N 8 Singaraja berbasis pada konsep-konsep terpadu dari berbagai disiplin ilmu. Pada hakikatnya IPS dikembangkan sebagai mata pelajaran dalam bentuk integrated social studies. Muatan IPS berasal dari geografi, sejarah, ekonomi, dan sosiologi. Berdasarlan hasil wawancara dengan guru di SMP N 8 Singaraja, pembelajaran IPS di sekolah tersebut terintegrasi dengan berbagai konsep dalam menggunakan pendekatan trans-disciplinarity di mana batas-batas disiplin ilmu tidak lagi tampak secara tegas dan jelas, karena konsepkonsep disiplin ilmu berbaur dan/atau terkait dengan permasalahanpermasalahan yang dijumpai di sekitarnya. Kondisi tersebut memudahkan pembelajaran IPS menjadi pembelajaran yang kontekstual.

Implementasi Kurikulum 2013 mata pelajaran IPS dilihat dari Standar Proses di SMP Negeri 8 Singaraja.

Standar Proses adalah kriteria mengenai pelaksanaan pembelajaran pada satuan pendidikan untuk mencapai Standar Kompetensi Lulusan. Standar Proses dikembangkan mengacu pada Standar Kompetensi Lulusan dan Standar Isi yang telah ditetapkan sesuai dengan ketentuan dalam Peraturan Pemerintah Nomor 19 Tahun 2005 tentang Standar Nasional Pendidikan sebagaimana telah diubah dengan Peraturan Pemerintah Nomor 32
Tahun 2013 tentang Perubahan atas Peraturan Pemerintah Nomor 19 Tahun 2005 tentang Standar Nasional Pendidikan Standar Kompetensi Lulusan memberikan kerangka konseptual tentang sasaran pembelajaran yang harus dicapai. Standar Isi memberikan kerangka konseptual tentang kegiatan belajar dan pembelajaran yang diturunkan dari tingkat kompetensi dan ruang lingkup.

Dalam kegiatan pembelajaran dimulai dari perencanaan, pelaksanaan, penilaian dan pengawasan. Berikut ini uraian terkait proses pembelajaran.

\section{Perencanaan Pembelajaran Silabus}

Menurut Mulyasa (2018) dalam Kurikulum 2013 pengembang silabus tidak lagi oleh guru, tetapi sudah disiapkan oleh tim pengembang kurikulum, baik ditingkat pusat ataupun wilayah. Dengan demikian guru tinggal mengembangkan RPP berdasarkan buku panduan guru, buku panduan siswa dan buku sumber yang semuanya telah disiapkan. Pengembangan silabus untuk setiap bidang studi dilakukan oleh tim pengembang kurikulum yang mencakup berbagai lembaga pendidikan, dengan berbagai kegiatan sebagai berikut.

1. Mengidentifikasikan dan menentukan jenis-jenis kompetensi dan tujuan setiap bidang studi.

2. Mengembangkan kompetensi dan pokok-pokok bahasan, serta mengelompokannya sesuai dengan ranah pengetahuan, pemahaman (keterampilan), nilai, dan sikap.

3. Mendiskripsikan kompetensi serta mengelompokannya sesuai dengan skope dan skuensi.

4. Mengembangkan indikator untuk setiap kompetensi serta kreteria pencapainnya.

Untuk kurikulum nasional, penyususun silabus mengacu pada Kurikulum 2013 dan perakat komponenkomponenya yang disusun oleh Pusat Kurikulum, Badan Penelitian dan Pengembangan, Kemendikbud. Untuk kurikulum wilayah, silabus dikembangkan oleh Tim Pengembang Kurikulum Wilayah. Namun demikian, sekolah yang mempunyai kemampuan mandiri dapat 
menyusun silabus yang sesuai dengan kondisi dan kebudayaan setempat (provinsi, kabupaten/kota). Penyusunan silabus dapat dilakukan dengan melibatkan para ahli atau instansi yang relevan di daerah stempat seperti tokoh masyarakat, instansi pemerintah, instansi swasta termasuk perusahaan dan industri, atau perguruan tinggi. Bantuan dan bimbingan teknis untuk penyusunan silabus sepanjang diperlukan dapat diberikan oleh Pusat Kurikulum.

\section{Rencana Pelaksanaan Pembelajaran}

Berangkat dari latar belakang yang telah dipaparkan di atas mengenai betapa pentingnya perencanaan pembelajaran dalam proses pembelajaran, hasil penelitian ini juga menfokuskan pada kesesuaian RPP dan proses pembelajaran di tingkat SMP melalui daring. Peneliti merasa perlu untuk mengetahui dan meneliti perencanaan pembelajaran yang dibuat oleh guru dalam hal ini Rencana Pelaksanaan Pembelajaran (RPP) dan kesesuaiannya dengan proses pembelajaran di situasi nyata. RPP pembelajaran daring hanya berjumlah 1 lembar dengan detail deskripsi kegiatan belajar dan indikator capaian pembelajaran yang harus dicapai peserta didik dalam mata pelajaran IPS. RPP dari SMPN 8 Singaraja terlampir di penelitian ini. Implementasi Kurikulum 2013 mata pelajaran IPS dilihat dari Standar Penilaian di SMP Negeri 8 Singaraja.

Penilaian dan pengisian angka rapor pada masa pandemi covid-19 menjadi permasalahan serius, selain kegiatan pembelajaran itu sendiri. Khususnya terkait dengan prinsip keadilan (equity) dan inklusivitas (inclusivity). Dalam situasi normal saja, penilaian dan pemberian nilai untuk rapor (grading), sebagai bentuk akuntabilitas program pembelajaran yang diselenggarakan guru/sekolah kepada pemangku kepentingan pendidikan (seperti orang tua siswa dan pemerintah), merupakan permasalahan rumit bagi guru. Terlebih pada masa pandemi, saat pembelajaran dan penilaian harus dilakukan dengan jarak jauh secara daring, serta menimbang kondisi dan latar belakang siswa sangat beragam baik secara ekonomi, budaya, maupun pendidikan keluarga. Sebagian siswa yang hidup dengan keterbatasan ekonomi, siswa berkebutuhan khusus, penyandang disabilitas, dan populasi terpinggirkan lainnya, selalu akan menghadapi hambatan belajar di sekolah. Dalam situasi normal, banyak sekolah membangun skema/unit pendukung yang dirancang untuk membantu siswa-siswa tersebut dalam mengatasi persoalan yang dihadapi, khususnya dalam mengatasi hambatan pembelajaran. Namun, sebagian daya dukungan itu tidak bisa digunakan dalam konteks pembelajaran jarak jauh. Sebagai contoh, hambatan pembelajaran yang dihadapi siswa yang kurang beruntung secara ekonomi, menjadi lebih tinggi dalam beberapa bulan terakhir sejak diselenggarakannya pendidikan jarak jauh melalui metode daring.Banyak siswa tidak memiliki akses ke internet atau mereka punya akses, tetapi jaringan internet yang tersedia tidak stabil. Masalah lain, yakni tidak memiliki akses ke perangkat pembelajaran yang diperlukan, gawai yang memadai, seperti telepon pintar (smartphone), tablet, atau komputer.

Menurut data yang diperoleh peneliti di atas menunjukan bahwa seluruh siswa di SMP N 8 Singaraja untuk menunjang keberlangsungan pembelajaran daring dengan menggunakan metode Information search mata pelajaran IPS siswa biasa menggunakan handphone atau laptop untuk akses internet saat pembelajaran daring. Hal ini dikarenakan zaman sekarang sudah mulai menjadikan smartphone adalah kebutuhan primer mereka.

Dengan adanya teknologi informasi mempermudah kegiatan pembelajaran ketika harus dilakukan secara daring seperti saat sekarang, hal ini dikarenakan dengan memanfaatkan internet menjadikan belajar lebih fleksibel karena siswa dengan sendirinya bisa mengakses informasi dengan mudah dan cepat dalam menyelesaikan tugas yang diberikan oleh guru.

Kelebihan pembelajaran daring menggunakan metode information search ini yaitu, menjadikan siswa belajar lebih mandiri dalam mengakses informasi tanpa 
menunggu materi yang harus dijelaskan oleh guru dan menjadikan siswa mengingat pembelajaran lebih dalam karena siswa secara otomatis akan membaca materi terlebih dahulu untuk menjawab soal dan menulisnya kembali. Kekurangan pembelajaran daring menggunakan metode information search ini yaitu, selain siswa tidak bisa berinteraksi secara langsung dengan guru, terdapat faktor lain yang menjadi pembelajaran tidak berlangsung secara maksimal karena diharuskan menggunakan paket data ketika pembelajaran daring berlangsung, serta harus ditunjang kekuatan sinyal yang bagus. Jadi hal itu menjadi poin penting untuk keberlangusngan pembelajaran daring.

Menurut data yang diperoleh peneliti di atas menunjukan bahwa seluruh siswa di SMP N 8 Singaraja sejauh ini siswa paham dengan materi yang disampaikan melalui pembelajaran daring oleh Bapak dan Ibu guru selaku guru yang mengampu mata pelajaran IPS. Hal ini dikarenakan siswa lebih banyak membaca terlebih dahulu sebelum menulis jawaban dari soal yang diberikan oleh guru.

Dari teori-teori yang sudah dipaparkan di atas mengenai pembelajaran daring dan metode information search, ditambah dengan wawancara singkat yang dilakukan oleh peneliti dengan guru mata pelajaran IPS dan siswa di SMP $\mathrm{N} 8$ Singaraja maka peneliti menyimpulkan bahwa penggunaan metode information search saat pembelajaran daring di mata pelajaran IPS bisa diterapkan karena ditengah-tengah problematika pembelajaran saat ini dengan keadaan Indonesia yang terdampak Covid-19 memang sedang menjadi hal utama untuk segara di pecahkan untuk mencari solusinya. Sesuai dengan teori maka penggunaan metode information search bisa gunakan untuk mata pelajaran IPS. Karena materi IPS yang pembahasannya sangat luas sehingga tidak akan efektif jika dijelaskan hanya melalui metode ceramah , tetapi jika terdapat tampilan video atau gambar yang bisa diambil atau dicari lewat internet akan menjadi penjelas dan alat bantu untuk siswa dalam memahami materi tidak hanya dengan bayangan pemikirannya saja. Akan tetapi penggunaan metode information search dalam pembelajaran daring ini tidak bisa digunakan untuk seluruh mata pelajaran rumpun IPS atau KD (Kompetensi Dasar) dalam kurikulum IPS karena hanya relevan digunakan untuk mata pelajaran atau KD (Komptensi Dasar) tentang pengetahuan umum karena mata pelajaran tersebut berisi banyak materi dan tanpa harus ada pertemuan antara guru dan siswa, jadi mata pelajaran tersebut dapat berlangsung dengan menggunakan metode information search dengan dibimbing oleh guru, sehingga penggunaan metode information search untuk mata pelajaran IPS bisa berjalan dengan efektif.

Adapun evaluasi yang dilakukan dari pembelajaran daring dengan menggunakan metode information search yaitu ketika siswa selesai menjawab soal yang diberikan oleh guru, selanjutnya guru memberikan post test secara online lewat groub WA dan siswa menjawab secara acak sebelum pembelajaran secara online ditutup oleh guru. Selain itu evaluasi yang dilakukan untuk meningkatkan keaktifan siswa dalam proses belajar, meminimalkan rasa bosan atau jenuh siswa terhadap, siswa diberi kesempatan dan kebebasan untuk mencari informasi sebagai sumber hasil pembelajaran, dan proses belajar lebih dipentingkan dari pada hasil.

\section{Pembahasan}

Implementasi kurikulum 2013 di masa pandemi seperti saat ini masih tetap dijadikan acuan oleh tenaga pendidik. Namun kenyataannya, standar dalam kurikulum 2013 tidak dapat diimplementasikan secara utuh mengingat situasi dan kondisi yang mendukung. Artinya, e-learning bagaimanapun canggihnya teknologi yang digunakan belum mampu menggantikan pelaksanaan pembelajaran tatap muka karena metode interaksi tatap muka konvensional masih jauh lebih efektif dibandingkan pembelajaran online atau e-learning. Selain itu, keterbatasan dalam aksesibilitas Internet oleh siswa seperti kuota pulsa, dan keterbatasan biaya orang tua dalam memberikan dukungan pembelajaran tersebut sering menjadi habatan dalam memaksimalkan proses belajar online. 
Namun dari kebijakan yang dikeluarkan tentunya tidak dapat memastikan semuanya akan berjalan sebagaimana mestinya disemua kalangan, khusus nya sekolah didesa-desa yang kekurangan fasilitas berupa teknologi terpadu guna menunjang proses pembelajaran belajar online. Kurangnya biaya dan fasilitas yang memadai antara guru dengan siswa/i nya membuat proses pembelajaran online tidaklah seefektif yang diharapkan.

Oleh karena itu, untuk menjawab rumusan masalah dari penelitian ini, maka seluruh proses pembelajaran dari persiapan, pelaksanaan hingga evaluasi dari kurikulum 2013 telah diteliti oleh penulis dalam situasi proses belajarmengajar secara daring sesuai dengan kondisi riil (nyata) yang terjadi disekolah SMP N 8 Singaraja. Pembelajaran daring menurut Gunawan yaitu pembelajaran dimana siswa menyelesaikan tugasnya dan mengambil keputusan setiap waktu dengan memanfaatkan teknologi (Gunawan et al., 2020)

Kualifikasi kemampuan lulusan yang dituangkan dalam Standar Kompetensi Lulusan (SKL) dalam mata pelajaran IPS dimensi sikap telah dinilai dari perilaku secara tidak langsung saat pembelajaran online. Penilaian dimensi sikap dinilai dari keaktifan peserta didik dalam merespon komunikasi guru dalam memberikan tugas di aplikasi group WA tersebut. Penilaian terhadap dimensi pengetahuan dilakukan dengan memberikan pertanyaan ataupun tugas-tugas kepada peserta didik. Ketepatan batas waktu pengumpulan dari jawaban tersebut, serta kreativitas peserta didik dalam mengerjakan tugas merupakan aspek dalam penilaian dimensi pengetahuan sekaligus dimensi keterampilan masing-masing peserta didik. Standar penilaian dalam implementasi kurikulum 2013 pada masa pandemi covid19 menjadi permasalahan serius, selain kegiatan pembelajaran itu sendiri. Khususnya terkait dengan prinsip keadilan (equity) dan inklusivitas (inclusivity). Sehingga, hal yang menjadi acuan tidak hanya dari nilai akhir peserta didik tetapi juga partisipasi aktif selama keberlangsungan proses belajar daring.

\section{SIMPULAN DAN SARAN}

Dari hasil penelitan yang telah dilaksanakan dapat diambil kesimpulan bahwa Implementasi Kurikulum 2013 di SMP N 8 Singaraja dilihat dari Standar Kompetensi Lulusan sudah berjalan dengan baik walaupun masih mengalami beberapa kendala. Ada 4 dimensi sikap yang dinilai yaitu dimensi sikap dan pengetahun. Pada situasi pandemic Covid19 ini kedua dimensi ini telah dinilai dari secara tidak langsung melalui mekanisme pembelajaran online. Implementasi Kurikulum 2013 di SMP N 8 Singaraja dilihat dari Standar Isi sudah berjalan baik. Pada proses pembelajaran IPS kelas VIII SMP N 8 Singaraja belum sepenuhnya sesuai dengan RPP yang telah dibuat oleh guru dikarenakan pembelajaran tatap muka yang belum bisa terlaksana karena situasi pandemi covid-19. Guru melaksanaan pembelajaran saintifik melalui platform media sosial seperti whatsapp group dengan memberikan materi pelajaran dan juga tugas untuk membuat siswa aktif dan mampu berpikir ilmiah. Implementasi Kurikulum 2013 di SMP N 8 Singaraja dilihat dari Standar Proses dalam situasi pandemi saat ini lebih banyak dilihat dari keaktifan dan kemampuan peserta didik untuk memahami materi yang telah diajarkan dan kemudian merespon tugas yang diberikan. Selain itu peserta didik juga harus menunjukkan sikap yang baik dalam kegiatan pembelajaran baik diskusi di group maupun ketepatan waktu pengumpulan tugas. Penilaian dari aspek sikap atau afektif dilihat dari sikap peserta didik dalam proses pembelajaran daring. Penilaian dari aspek pengetahuan atau kognitif dilihat dari kemampuan peserta untuk menguasai materi pelajaran. Penilaian dari aspek keterampilan atau psikomotor bisa dilihat dari keterampilan siswa untuk menjawab persoalan yang diberikan oleh guru. Implementasi Kurikulum 2013 di SMP N 8 Singaraja dilihat dari Standar Kompetensi Penilaian sudah berjalan dengan baik walaupun masih mengalami beberapa kendala. Standar penilaian dalam implementasi kurikulum 2013 pada masa pandemi covid- 
19 menjadi hal yang sangat penting bagi guru saat ini selain kegiatan pembelajaran itu sendiri. Khususnya terkait dengan prinsip keadilan (equity) dan inklusivitas (inclusivity). Sehingga, hal yang menjadi acuan tidak hanya dari nilai akhir peserta didik tetapi juga partisipasi aktif selama keberlangsungan proses belajar daring.

\section{Saran}

Berdasarkan penelitian di atas, kurikulum 2013 diharapkan dapat berjalan dengan baik jika sekolah dapat memahami konsep pelaksanaannya dengan baik. Untuk itu diperlukan pelatihan dan pendampingan tentang Kurikulum 2013 baik dari pemerintah ataupun pihak sekolah. Proses penilaian di sekolah yang berdasarkan Kurikulum 2013 dapat dikatakan sudah berjalan dengan cukup baik. Hal ini hendaknya menjadi motivasi bagi sekolah untuk terus meningkatkan kualitas pendidikan agar tujuan pendidikan dapat tercapai. Dalam pelaporan penilaian diperlukan penguasaan IT yang baik oleh guru. Untuk itu diperlukan semangat dari guru untuk melaksanakan pelatihan IT untuk menunjang pelaksanaan Kurikulum 2013 dengan baik. Dalam hal ini, guru sebagai pelaksana kegiatan pembelajaran diharapkan dapat memahami implementasi Kurikulum 2013 dengan baik terutama dalam proses pembelajaran. Hal ini dapat dilakukan dengan memaksimalkan peran MGMP dan banyak mengikuti pelatihan tentang Kurikulum 2013 baik yang diadakan oleh pemerintah maupun sekolah. Peran guru dalam memilih media, metode, strategi dan model pembelajaran yang bervariasi sangat diharapkan untuk membuat siswa aktif dalam kegiatan pembelajaran. Selain itu, buku pelajaran merupakan faktor pendukung dalam kegiatan pembelajaran. Pemerintah sebaiknya lebih banyak memberikan buku pelajaran ke sekolah agar proses pembelajaran dapat berjalan dengan baik. Guru sebaiknya juga menggunakan buku pelajaran dari sumber lain yang dimiliki karena untuk materi pelajaran tetap sama dengan kurikulum yang sebelumnya. Adanya kendala-kendala yang dialami sekolah dalam implementasi Kurikulum 2013 diharapkan dapat dijadikan motivasi agar dapat memperbaiki diri dan mampu menerapkan Kurikulum 2013 dengan maksimal.

\section{DAFTAR PUSTAKA}

Adib Rifqi Setiawan \& Surotul Ilmiyah. (2020). Lembar Kegiatan Siswa untuk Pembelajaran Jarak Jauh Berdasarkan Literasi Saintifik pada Topik Penyakit Coronavirus 2019 (COVID-19).

Afifah, S. N. (2017). Implementasi Kurikulum 2013 pada Mata Pelajaran IPS Terpadu di MTsN Malang 1. 26, 169-177.

Afrizal, M. A. (2016). Metode Penelitian Kualitatif: Sebuah Upaya Mendukung Penggunaan Penelitian Kualitatif dalam Berbagai Disiplin IImu. Jakarta: Rajawali Pers.

Emusti, R. ., \& Karel, J. (2019). Implementasi kurikulum dalam pembelajaran IPS Terpadu di SMP Negeri Kota Singkawang. SOSIAL HORIZON: Jurnal Pendidikan Sosial IKIP PGRI Pontianak, 6(2).

Fussalam, Y. E., \& Elmiati. (2018). Implementasi Kurikulum 2013 (K13) Smp Negeri 2 Sarolangun 1. 3(1).

Gunawan, A., Malik, A., Zakir, M. I., Ilhamiyah, \& Zuraida, A. (2020). Efektivitas Dan Pengalaman Pembelajaran Daring Di Fakultas Pertanian Universitas Islam Kalimantan Muhammad Arsyad Al Banjari Banjarmasin. Jurnal Pengabdian Al-Iklas, 6(2), 220-227.

Jannah, E. M. (2013). Implementasi Kurikulum 2013 pada Mata Pelajaran IPS di SMP Negeri 1 Muntilan. Jurnal Pendidikan IImu Pengetahuan Sosial. Universitas Negeri Yogyakarta.

Mastur. (2017). Implementasi Kurikulum 2013 Dalam Pelaksanaan Pembelajaran Di Smp. 4(1), 50-64.

Mulyasa, E. (2018). Implementasi Kurikulum 2013 Revisi. Jakarta Timur: PT. Bumi Aksara.

Prastowo, A. (2015). Menyusun Rencana Pelaksanaan Pembelajaran (RPP) Tematik Terpadu Implementasi Kurikulum 2013 untuk SD/MI. Jakarta: Prenadamedia Group.

Priyatni, E. T. (2017). Desain Pembelajaran 
Bahasa Indonesia dalam Kurikulum 2013. Jakarta Timur: PT. Bumi Aksara.

Setiana, N. (2014). Pembelajaran Ips Terintegrasi Dalam Konteks Kurikulum 2013. 95-108.

Setyosari, P. (2012). Metode Penelitin Pendidikan dan Pengembangan. Kencana.

Siregar, S. (2013). Metode Penelitian Kuantitatif: Dilengkapi Perbandingan Perhitungan Manual \& SPSS. Jakarta: Pranadamedia Group.

Solihatin, E. dan R. (2011). Cooperative Learning analisis model pembelajaran IPS. Jakarta Timur: PT. Bumi Aksara.

Sugiyono. (2014). Metode Penelitian Bisnis (Pendekatan Kuantitatif, Kualitatif dan $R \& D)$. Bandung: Alfabeta.

Sugiyono. (2015). Metode Penelitian Pendidikan (Pendekatan Kuantitatif, Kualitatif dan R\&D). Bandung: CV. Alfabeta.

Sukardi. (2012). Metodologi Penelitian Pendidikan. Jakarta Timur: PT. Bumi Aksara. 